\title{
Thermotolerance and the Heat-shock Response in Candida albicans
}

\author{
By MARIE L. ZEUTHEN AND DEXTER H. HOWARD* \\ Department of Microbiology and Immunology, UCLA School of Medicine, Los Angeles, \\ California 90024, USA
}

(Received 6 January 1989; revised 5 May 1989; accepted 26 May 1989)

\begin{abstract}
At elevated temperatures, yeast cells of Candida albicans synthesized nine heat-shock proteins (HSPs) with apparent molecular masses of 98, 85, 81, 76, 72, 54, 34, 26 and $18 \mathrm{kDa}$. The optimum temperature for the heat-shock response was $45^{\circ} \mathrm{C}$ although HSPs were detected throughout the range $41-46^{\circ} \mathrm{C}$. Protein synthesis was not observed in cells kept at $48^{\circ} \mathrm{C}$. Yeast cells survived exposure to an otherwise lethal temperature of $55^{\circ} \mathrm{C}$ when they had previously been exposed to $45^{\circ} \mathrm{C}$. The thermotolerance induced during incubation at $45^{\circ} \mathrm{C}$ required protein synthesis, since protection was markedly reduced by trichodermin. Mercury ions induced a set of three stress proteins, one of which corresponded in size to an HSP, and cadmium ions evoked one stress protein seemingly unrelated to the HSPs observed after temperature shift.
\end{abstract}

\section{INTRODUCTION}

Prokaryotic and eukaryotic cells respond to a sudden change of temperature by the increased production of an array of proteins called heat-shock proteins (HSPs). These HSPs may be induced by heat stress or may be constitutive proteins whose production is markedly increased as a response to such stress. In every system where heat shock has been investigated HSPs have been found (Lindquist, 1986). In some organisms production of HSPs has been associated with an increase in thermotolerance, i.e., an enhanced ability of organisms to survive exposure to otherwise lethal temperatures (Carper et al., 1987; Plesset et al., 1982; Plesofsky-Vig \& Brambl, 1985).

The opportunistic fungus Candida albicans grows as a yeast-form that reproduces by budding on most media when incubated at room temperature $\left(23-25^{\circ} \mathrm{C}\right)(\mathrm{Odds}, 1988)$. The yeast cells form germ tubes in media that contain germ-tube-inducing ingredients when shifted from $23{ }^{\circ} \mathrm{C}$ to $37^{\circ} \mathrm{C}$ at pH 6.5-7.0 (Dabrowa \& Howard, 1983). Such a temperature shift also evokes HSPs (Dabrowa \& Howard, 1984; Zeuthen et al., 1988). It has been suggested that HSPs might be involved in some aspects of growth and differentiation of cells (Carper et al., 1987; LeJohn \& Braithwaite, 1984; Lindquist, 1986; Schlesinger, 1986; Wanner et al., 1985), yet the HSPs observed after a temperature shift from $23{ }^{\circ} \mathrm{C}$ to $37^{\circ} \mathrm{C}$ would appear not to be involved in the germination of $C$. albicans in the warm-blooded host since the yeasts do not experience a temperature shift under these circumstances, although tissue invasion is often initiated by germtube emergence (Borg \& Rüchel, 1988; Odds, 1988; Ray \& Payne, 1988). However, it is wellknown that forms of stress other than heat shock may evoke HSPs and it is, therefore, possible that HSPs produced by stimuli other than heat may play a role in germ-tube formation in a warm-blooded host (Jenkins et al., 1988; LeJohn \& Braithwaite, 1984). We have continued our study of the HSPs of $C$. albicans by assessing the stress response of cells shifted from $37^{\circ} \mathrm{C}$ to supraoptimal temperatures $\left(41-46^{\circ} \mathrm{C}\right)$, temperature shifts that are not accompanied by germtube formation. These studies were made to observe the heat-shock response independent of morphogenetic changes and to compare the response to that evoked by other forms of stress.

\footnotetext{
Abbreviations: HSP, heat-shock protein; GPA, glucose/peptone agar; YNB, yeast nitrogen base (without amino acids); YNBG, YNG $+1 \%(w / v)$ glucose.
} 


\section{METHODS}

Organisms. The Candida albicans strains used in the study were strain 300 (Dabrowa \& Howard, 1984; National Collection of Pathogenic Fungi, NCPF 3153A), strain 300-SG (Howard et al., 1986), strain 320 (Gibbons \& Howard, 1986) and strain 336, a recent isolate (Zeuthen et al., 1988). Strains 300, 320 and 336 formed germ tubes under standard test conditions (Zeuthen et al., 1988) while strain 300-SG was germination deficient (Howard et al., 1986). Stock cultures are preserved in the Fungus Collection, University of California, Los Angeles, CA, USA. Working cultures were maintained on GPA (see below) in a refrigerator and subcultured every month.

Media. Glucose/peptone agar (GPA) contained 2\% (w/v) Bacto Dextrose (Difco), $1 \%$ (w/v) Bacto Peptone (Difco) and $2 \%$ (w/v) Bacto Agar (Difco). Yeast Nitrogen Base without amino acids (YNB) was prepared in accordance with the manufacturer's instructions (Difco). YNBG was YNB with $1 \%$ (w/v) Bacto Dextrose (Difco). Chemicals, including amino acids, were purchased from Sigma, Calbiochem or Eastman Kodak.

Analysis of the heat shock response. Cells were grown overnight in YNBG at $37^{\circ} \mathrm{C}$ and used to inoculate $50 \mathrm{ml}$ of fresh YNBG contained in $300 \mathrm{ml}$ nepheloflasks with side-arms (Bellco Glass). The cultures were grown on a rotary shaker (New Brunswick) at $37^{\circ} \mathrm{C}$ and growth was assessed at regular intervals by measuring optical density (OD) with a Klett-Summerson photoelectric colorimeter (red filter). Growth was interrupted and cultures used at the mid-exponential phase of growth (Howard et al., 1986). Cells were harvested, washed in distilled water and resuspended at $1 \times 10^{8}$ cells ml ${ }^{-1}$ in YNBG prewarmed to the different temperatures studied $\left(40-46^{\circ} \mathrm{C}\right)$. Proteins were labelled with L- $\left[{ }^{35}\right.$ S $]$ methionine (specific activity $45 \mathrm{TBq} \mathrm{mmol}^{-1}$ ) to a final concentration of $3.7 \mathrm{MBq} \mathrm{ml}^{-1}$ for a $15 \mathrm{~min}$ pulse. Labelling was stopped by addition of unlabelled DL-methionine (final concentration $650 \mu \mathrm{M}$ ). The cells were immediately placed on ice, washed in distilled water, and held as a pellet at $-20^{\circ} \mathrm{C}$ until they were prepared for electrophoresis.

Effect of heavy metals on protein synthesis. Cells were grown in YNBG at $37^{\circ} \mathrm{C}$, harvested, washed and standardized as described in the preceding paragraph. About $1 \times 10^{8}$ cells $\mathrm{ml}^{-1}$ were added to YNBG containing separately $10 \mu \mathrm{M}$-phenylmercuric acetate, and 1, 20 and $40 \mathrm{mM} \mathrm{CdCl}_{2}, \mathrm{SrCl}_{2}$ or $\mathrm{SnCl}_{2}$. Proteins were labelled and stored for electrophoresis as described in the preceding paragraph.

Thermal death time. Cells were grown at $37^{\circ} \mathrm{C}$ as described above. Growth was interrupted and cells used during the exponential and stationary phases of growth (Howard et al., 1986). Cells were harvested at the desired phase of growth, washed in distilled water and resuspended at a concentration of $5 \times 10^{6} \mathrm{cells} \mathrm{ml}^{-1}$ in YNBG prewarmed to $55^{\circ} \mathrm{C}$. Samples were removed at regular intervals, diluted and spread on GPA. Colonies (c.f.u.) were counted after 5-7 d incubation at room temperature. Both mid-exponential and stationary phase cells were tested.

Thermotolerance. Preliminary experiments established that $C$. albicans strain 300 survived exposure to temperatures in the range $40-46^{\circ} \mathrm{C}$. The lethal temperature of $55^{\circ} \mathrm{C}$ used in the thermal-death time experiments (preceding paragraph) was arbitrarily chosen to be well above the range of tolerated supraoptimal temperatures.

The induction of thermotolerance was tested by shifting cells, grown and prepared as described above, from $37^{\circ} \mathrm{C}$ to selected supraoptimal temperatures $\left(40-46^{\circ} \mathrm{C}\right)$ for $30 \mathrm{~min}$. All media were prewarmed to the temperature studied. The temperature-exposed cells were shifted to the prewarmed YNBG at the lethal temperature $\left(55^{\circ} \mathrm{C}\right)$. Samples were withdrawn at intervals, diluted in distilled water and spread on GPA. Colonies were counted after 5-7 d incubation at room temperature. The results of each experimental treatment are expressed as a percentage of controls kept at $37^{\circ} \mathrm{C}$. To test for the requirement for protein synthesis in the induction of thermotolerance, $3.5 \mu \mathrm{g}$ trichodermin $\mathrm{ml}^{-1}$ was added to YNBG $20 \mathrm{~min}$ before a shift from $37^{\circ} \mathrm{C}$ to $43^{\circ} \mathrm{C}$ or to $45^{\circ} \mathrm{C}$. The trichodermin was left in the medium during the $30 \mathrm{~min}$ incubation at $43^{\circ} \mathrm{C}$ or $45^{\circ} \mathrm{C}$. Cells preincubated at $43^{\circ} \mathrm{C}$ or $45^{\circ} \mathrm{C}$ in the presence of trichodermin were shifted to $55^{\circ} \mathrm{C}$. After the shift to $55^{\circ} \mathrm{C}$, samples were withdrawn at selected intervals, diluted and cultured as indicated previously. Trichodermin was a gift from W. O. Godtfredsen, Leo Pharmaceuticals, Ballerup, Denmark.

Polyacrylamide gel electrophoresis. Cells from experiments designed to study the stress response were washed twice and suspended in $0.4 \mathrm{ml} 1 \mathrm{~mm}$-phenylmethylsulphonyl fluoride in water. Glass beads ( 2 vols, $0.45 \mathrm{~mm}$ ) were added to each tube. Cells were broken by mixing on a vortex mixer (Vortex-Genie) at maximum speed for six periods of $30 \mathrm{~s}$ each. Cells were kept on ice except during vortex mixing. Microscopic examination revealed that $90-95 \%$ of the cells were broken. Beads and cell wall debris were pelleted by centrifugation. The supernatant containing crude protein was added to an equal volume of $0.1 \mathrm{M}-\mathrm{Tris} / \mathrm{HCl}$ ( $\mathrm{pH} 6.8$ ) containing $18 \%(\mathrm{v} / \mathrm{v}) \mathrm{glycerol}$, $1.8 \%(\mathrm{w} / \mathrm{v})$ SDS, $0.18 \%$ 2-mercaptoethanol and $0.0018 \%$ bromophenol blue, and was immediately heated at $100{ }^{\circ} \mathrm{C}$ for $2 \mathrm{~min}$. The radiolabelled proteins in the cell extracts were separated by one-dimensional SDS gel electrophoresis in $12 \%(w / v)$ polyacrylamide slab gels (Dabrowa \& Howard, 1984). The time of electrophoresis was approximately $3 \mathrm{~h}$. The amount of protein per lane was 10-15 $\mathrm{gg}$. Proteins were separated at a constant current of $25 \mathrm{~mA}$, fixed in methanol/acetic acid/water $(5: 4: 1$, by vol.) and stained by the silver nitrate method (Morrissey, 1981). After staining, the gels were dried onto GelBond PAG support paper (FMC BioProducts) and exposed to Kodak XAR-5 film at $-70^{\circ} \mathrm{C}$. Molecular mass markers were from Pharmacia. Reagents for electrophoresis were obtained from BRL and Sigma. 


\section{RESULTS}

\section{Heat-shock proteins}

HSPs were produced by $C$. albicans strain 300 after a shift to temperatures a few degrees above the normal growth temperature of $37^{\circ} \mathrm{C}$ (Fig. 1). HSPs could be demonstrated at elevated temperatures of $41{ }^{\circ} \mathrm{C}$ to $46^{\circ} \mathrm{C}$ (data not shown). At $48^{\circ} \mathrm{C}$ all protein synthesis stopped (data not shown). Exponential phase cells of strain 300 when shifted from $37^{\circ} \mathrm{C}$ to $45^{\circ} \mathrm{C}$ produced nine HSPs (Fig. 1). The apparent molecular masses were 98, 85, 81, 76, 72, 54, 34, 26 and $18 \mathrm{kDa}$. The values obtained in different experiments under the same conditions varied slightly but the variation of band positions among runs was less than $10 \%$. The HSPs were not the only proteins synthesized at temperatures above $37^{\circ} \mathrm{C}$ and a number of bands seen at $37^{\circ} \mathrm{C}$ were also seen at the same intensity at $45^{\circ} \mathrm{C}$ (Fig. 1). Three other strains of C. albicans, 300-SG, 320 and 336, synthesized HSPs of similar molecular mass to those synthesized by strain 300 .

\section{Studies on heavy metals}

A brief exposure of mammalian and avian cells to heavy metals causes the synthesis of proteins of similar molecular mass to some HSPs (Atkinson \& Dean, 1985; Li \& Laszlo, 1985; Schlesinger, 1985). We asked whether such substances would evoke a stress response in C. albicans. A preliminary series of observations were made with $\mathrm{CdCl}_{2}, \mathrm{SrCl}_{2}$ and $\mathrm{SnCl}_{2}$ (each at 1,20 and $40 \mathrm{mM})$, and mercury as the organomercurial phenylmercuric acetate $(10 \mu \mathrm{M})$. Only cadmium and mercury evoked the synthesis of new proteins and these were chosen for further work. Cells of strain 300 exposed to $20 \mathrm{mM}-\mathrm{CdCl}_{2}$ produced a single new protein of about $135 \mathrm{kDa}$ (Fig. 2; Table 2) and none of the stress proteins seen after heat shock or ethanol exposure (Zeuthen et al., 1988). Treatment of cells with $10 \mu \mathrm{M}$-phenylmercuric acetate resulted in three new proteins (Fig. 3) one of which corresponded in size to an HSP (81 kDa; Table 2), another of which was similar in size to an HSP ( $84 \mathrm{kDa}$; Table 2$)$, and one which was unique to exposure to the organomercurial $\left(88 \mathrm{kDa}\right.$; Table 2). Exposure of cells to levels of $\mathrm{CdCl}_{2}$ greater than $40 \mathrm{~mm}$ resulted in cessation of protein synthesis and eventual death of the cells. Higher levels of phenylmercuric acetate were not studied.

\section{Thermal death and induction of thermotolerance in C. albicans}

A temperature of $55^{\circ} \mathrm{C}$ was lethal for strain $300: 98 \%$ of the exponential phase cells died in 5 min after a shift from $37^{\circ} \mathrm{C}$ to $55^{\circ} \mathrm{C}$; it took 25 min to kill a similar proportion of stationary phase cells (Fig. $4 a$ ).

The lethality of exposure to $55^{\circ} \mathrm{C}$ was greatly reduced when cells were exposed to $45^{\circ} \mathrm{C}$ for 30 min before transfer to $55^{\circ} \mathrm{C}$ (Fig. $4 b$ ). The tolerance was induced to a more striking extent in stationary phase cells than it was in exponential phase cells (Fig. 4b). Induction of thermotolerance was tested over the range $40-46^{\circ} \mathrm{C}$. The time of incubation at each temperature was $30 \mathrm{~min}$. Cells incubated at $40^{\circ} \mathrm{C}$ for $30 \mathrm{~min}$ survived no better at $55^{\circ} \mathrm{C}$ than did those incubated at $37^{\circ} \mathrm{C}$ before the shift. Temperatures of $43-46^{\circ} \mathrm{C}$ conferred tolerance on cells shifted to $55^{\circ} \mathrm{C}$ (Fig. 5). For mid-exponential phase cells the most effective preincubation temperature was $45^{\circ} \mathrm{C}$ or $46^{\circ} \mathrm{C}$. The survival curves of cells preincubated at these two temperatures were virtually identical and only the data for $46^{\circ} \mathrm{C}$ are shown in Fig. 5 . A temperature of $45^{\circ} \mathrm{C}$ was selected for conditioning the cells in the subsequent experiments.

The time of preconditioning affected survival at $55^{\circ} \mathrm{C}$. Cells preincubated for $15 \mathrm{~min}$ at $45^{\circ} \mathrm{C}$ survived better than cells not preconditioned but the best survival was obtained with cells preconditioned for $30 \mathrm{~min}$ (data not shown). Cells preincubated at $45^{\circ} \mathrm{C}$ for longer periods were no better able to survive at $55^{\circ} \mathrm{C}$ (data not shown).

The data in Table 1 show that induction of thermotolerance was dependent on protein synthesis during preincubation. A short preincubation at $43^{\circ} \mathrm{C}$ or $45^{\circ} \mathrm{C}$ extended the survival of the cells when shifted to $55^{\circ} \mathrm{C}$. The protection accorded by preincubation at $43{ }^{\circ} \mathrm{C}$ or $45^{\circ} \mathrm{C}$ was markedly reduced when trichodermin was incorporated in the medium. Trichodermin at the level used inhibits protein synthesis (Shepherd et al., 1980; Gopal et al., 1982) but does not kill 


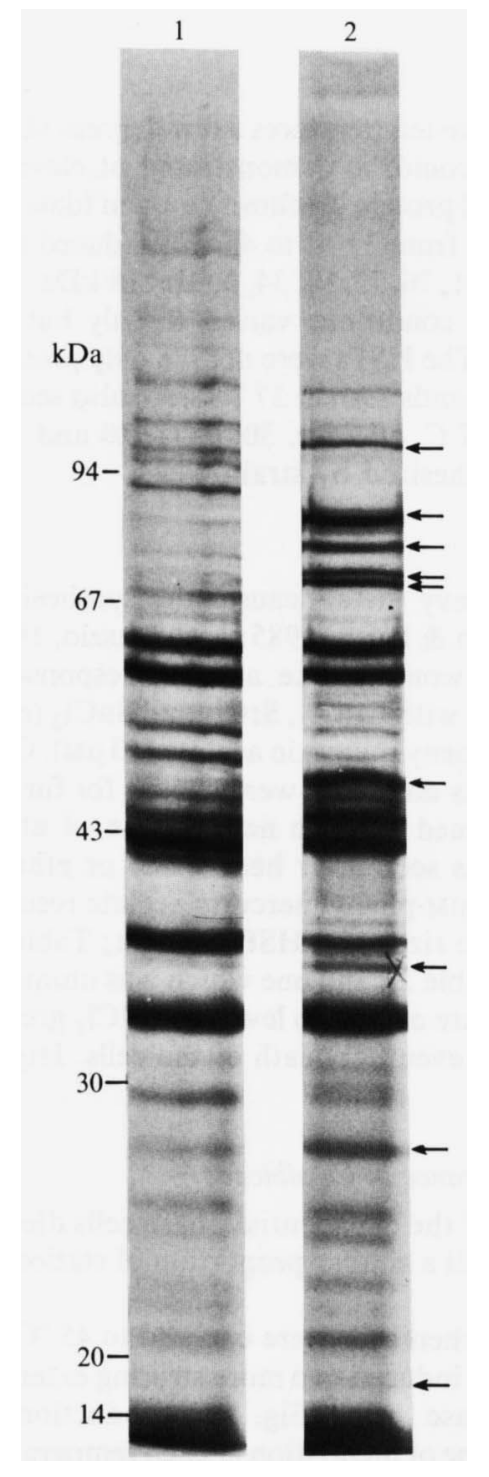

Fig. 1. Autoradiogram of cellular proteins separated by SDS-PAGE $(12 \%, \mathrm{w} / \mathrm{v}$, polyacrylamide). Cells of $C$. albicans strain 300 were grown in YNBG at $37^{\circ} \mathrm{C}$ and transferred to prewarmed YNBG. Lane $1,37^{\circ} \mathrm{C}$; lane $2,45^{\circ} \mathrm{C}$. Cells were pulse-labelled with $\mathrm{L}_{-}\left[{ }^{35} \mathrm{~S}\right] \mathrm{methionine}$ for $15 \mathrm{~min}$ during the period 15-30 min after the shift. Values on the left represent molecular mass standards. The arrows indicate HSPs.

C. albicans and, after removal of the drug, cells resume growth. A role for HSPs in thermotolerance was supported further by the following results. Cells of strain 300 that had been grown at $37^{\circ} \mathrm{C}$ were shifted to $45^{\circ} \mathrm{C}$ for $30 \mathrm{~min}$ and then shifted back to $37^{\circ} \mathrm{C}$. The HSPs formed (see Fig. 1) persisted for $1 \mathrm{~h}$ at $37^{\circ} \mathrm{C}$ but began to disappear after $2 \mathrm{~h}$. By $2.5 \mathrm{~h}$ HSPs were not detectable in the cells by gel electrophoresis. Such cells were no longer thermotolerant and died at $55^{\circ} \mathrm{C}$ as rapidly as cells that had not been preincubated at $45^{\circ} \mathrm{C}$ (data not shown).

Ethanol has been reported to induce thermotolerance in Saccharomyces cerevisiae (Plesset $e t$ al., 1982). In a series of six experiments we observed a slight induction of thermotolerance of C. albicans strain 300 by preliminary incubation of cells in $7 \%$ (v/v) ethanol for $30 \mathrm{~min}$ (Fig. 6). The cells were not killed by this exposure to $7 \%$ ethanol but they did synthesize stress proteins (Zeuthen et al., 1988). Induction of thermotolerance by ethanol was modest compared to that evoked by preincubation at $45^{\circ} \mathrm{C}$ (Fig. 6). 


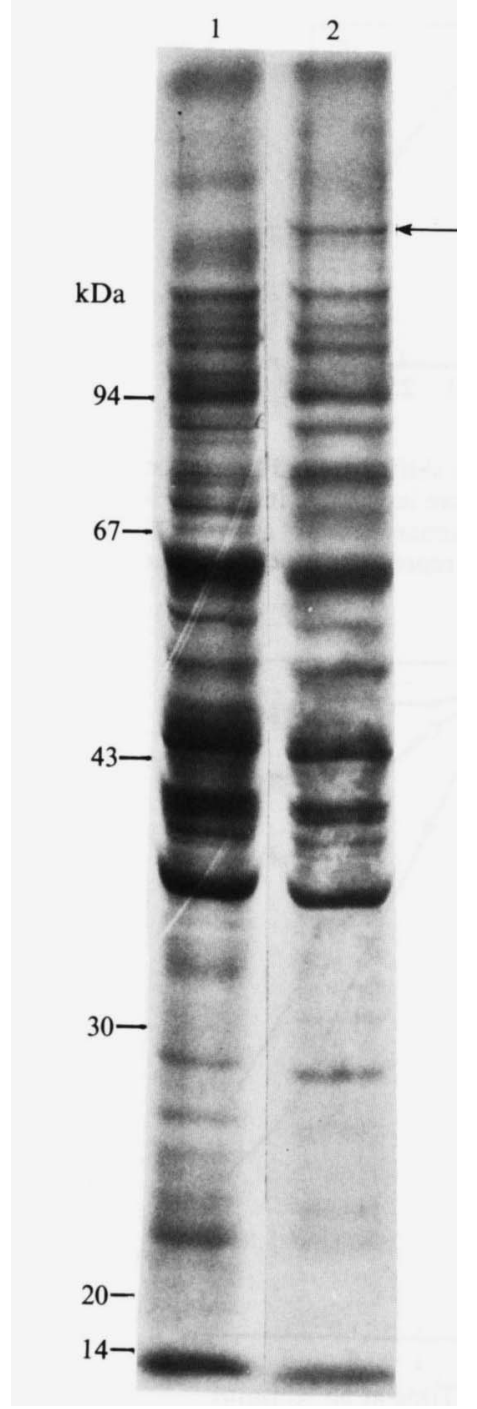

Fig. 2

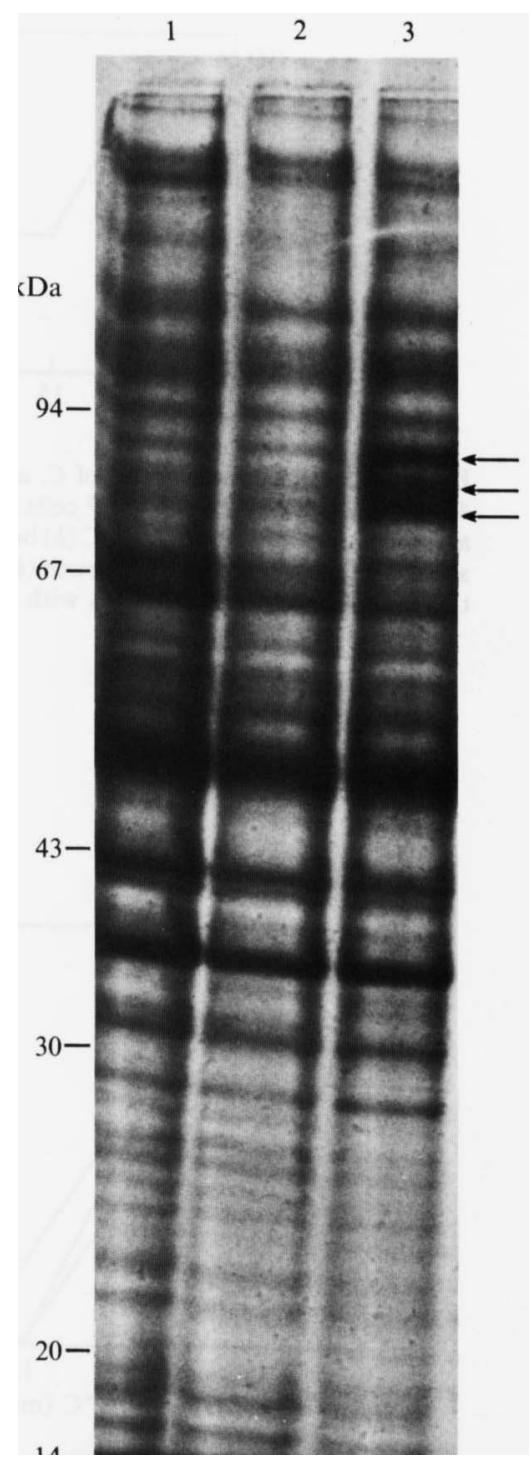

Fig. 3

Fig. 2. Autoradiogram of cellular proteins separated in the same manner as those shown in Fig. 1. Cells of $C$. albicans strain 300 were grown in YNBG at $37^{\circ} \mathrm{C}$, then transferred to prewarmed YNBG (lane 1) or YNBG supplemented with $20 \mathrm{mM}-\mathrm{CdCl}_{2}$ (lane 2). Cells were labelled with $\mathrm{L}-\left[{ }^{35} \mathrm{~S}\right]$ methionine during the period 15-30 min after transfer to medium with (lane 2) or without (lane 1) cadmium. Values on the left represent molecular mass standards. The arrow indicates the stress protein.

Fig. 3. Autoradiogram of cellular proteins separated in the same manner as those shown in Fig. 1. Cells of $C$. albicans strain 300 were grown in YNBG at $37^{\circ} \mathrm{C}$, then transferred to prewarmed $\left(37^{\circ} \mathrm{C}\right) \mathrm{YNBG}$ supplemented with $10 \mu \mathrm{M}$-phenylmercuric acetate and pulse-labelled with $\mathrm{L}-\left[{ }^{35} S\right]$ methionine. (Lane 1 , cells not exposed to mercury; lane 2, cells exposed to mercury; both pulse-labelled from 0-15 min during exposure to mercury. Lane 3, cells exposed to mercury and pulse-labelled from 15-30 min during exposure to mercury.) Values on the left represent molecular mass standards. Arrows indicating stress proteins are shown by lane 3 . 


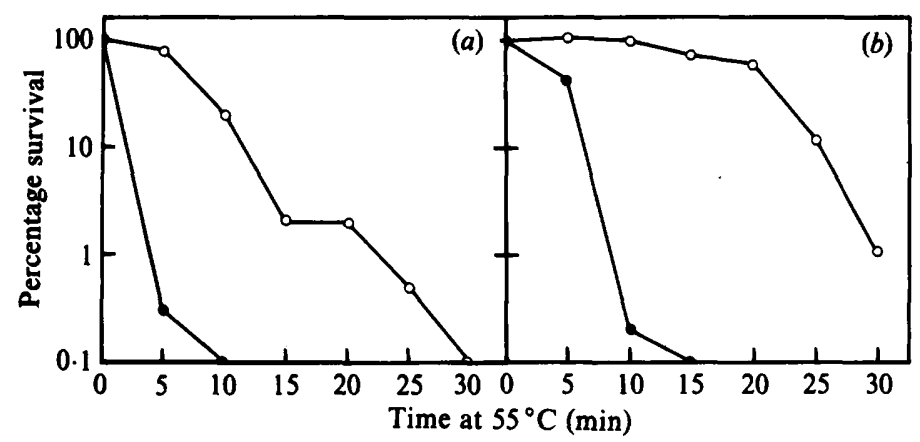

Fig. 4. Effect of growth phase of C. albicans strain 300 on survival of cells shifted from $37^{\circ} \mathrm{C}($ a) or $45^{\circ} \mathrm{C}(b)$ to $55^{\circ} \mathrm{C}$. About $5 \times 10^{6}$ cells $\mathrm{ml}^{-1}$ that had been grown at $37^{\circ} \mathrm{C}$ were inoculated into YNBG and incubated for $30 \mathrm{~min}$ at $45^{\circ} \mathrm{C}(\mathrm{b})$ before shift to $55^{\circ} \mathrm{C}$. Cells from the stationary phase of growth $(\mathrm{O})$ and the exponential phase of growth $(\bullet)$ were tested. The results are from a representative experiment that was repeated several times with similar results.

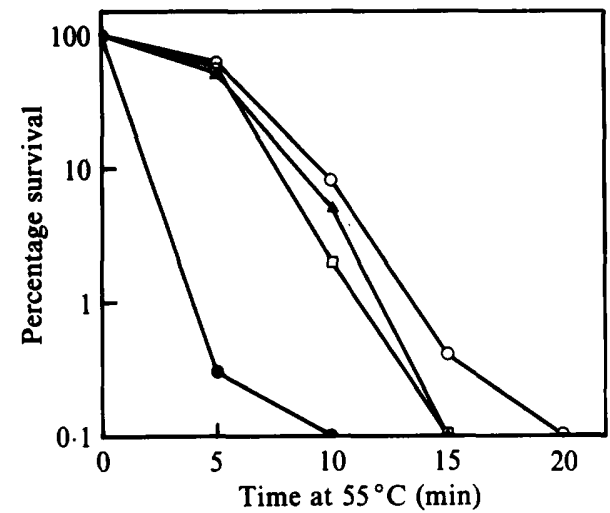

Fig. 5

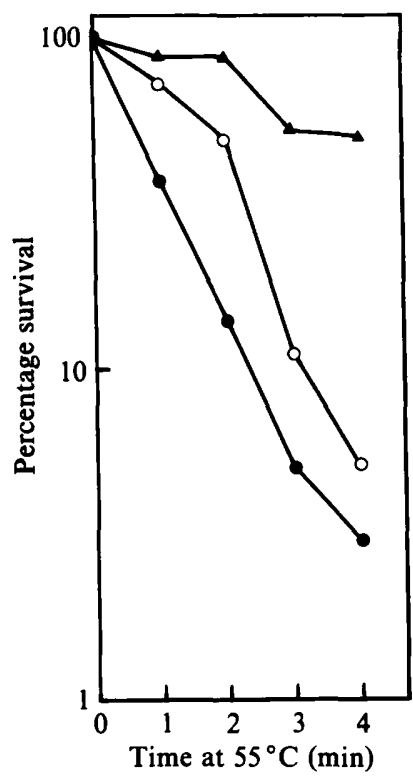

Fig. 6

Fig. 5. Survival of C. albicans strain 300 at $55^{\circ} \mathrm{C}$ after a preliminary incubation at a lower temperature. About $5 \times 10^{6}$ cells $\mathrm{ml}^{-1}$ that had been grown at $37^{\circ} \mathrm{C}$ were inoculated into YNBG. Cells were harvested in the exponential phase, resuspended in prewarmed media, and incubated for $30 \mathrm{~min}$ at $43^{\circ} \mathrm{C}(\square), 44^{\circ} \mathrm{C}(0)$ or $46^{\circ} \mathrm{C}(\triangle)$. The treated cells were then harvested and reincubated in fresh YNBG at $55^{\circ} \mathrm{C}$. Cells incubated at $37^{\circ} \mathrm{C}(\bullet)$ and shifted to $55^{\circ} \mathrm{C}$ served as controls. The results are from a single experiment that was repeated several times with similar results.

Fig. 6. Induction of thermotolerance in C. albicans strain 300 by preincubation at $45^{\circ} \mathrm{C}$ or exposure to $7 \%(\mathrm{v} / \mathrm{v})$ ethanol. Cells were grown to exponential phase in YNBG at $37^{\circ} \mathrm{C}$ and shifted to $55^{\circ} \mathrm{C}$. $\bullet$. No preliminary treatment of cells; $\triangle$, cells incubated for $30 \mathrm{~min}$ at $45^{\circ} \mathrm{C}$ before the shift to $55^{\circ} \mathrm{C} ; \mathrm{O}$, cells exposed to $7 \%(v / v)$ ethanol before the shift to $55^{\circ} \mathrm{C}$. The experiment was repeated five times with similar results.

\section{DISCUSSION}

Cells of $C$. albicans respond to supraoptimal temperatures with an obviously altered pattern of protein synthesis. At $45^{\circ} \mathrm{C}$ nine new proteins were synthesized. Five of the high molecular mass proteins, $98,85,81,76$ and $72 \mathrm{kDa}$, are similar in molecular size to the highly conserved families 
Table 1. Importance of protein synthesis in the induction of thermotolerance in C. albicans

About $5 \times 10^{6}$ cells $\mathrm{ml}^{-1}$ of $C$. albicans strain 300 were grown to exponential phase in YNBG, harvested, washed and distributed to culture vessels. After the time periods in min indicated in parentheses, samples were removed, diluted and plated on GPA. Colonies were counted after incubating plates for $7 \mathrm{~d}$ at room temperature. The temperature shifts were as shown and trichodermin was added to one vessel (T) before preincubation at $43^{\circ} \mathrm{C}$ and $45^{\circ} \mathrm{C}$. Results are from a representative experiment.

Temperature shift (time in min)

$$
\begin{aligned}
& 37^{\circ} \mathrm{C} \rightarrow 37^{\circ} \mathrm{C}(30) \\
& 37^{\circ} \mathrm{C} \rightarrow 43^{\circ} \mathrm{C}(30) \\
& 37^{\circ} \mathrm{C} \rightarrow 45^{\circ} \mathrm{C}(30) \\
& 37^{\circ} \mathrm{C} \rightarrow 55^{\circ} \mathrm{C}(8) \\
& 37^{\circ} \mathrm{C} \rightarrow 43^{\circ} \mathrm{C}(30) \rightarrow 55^{\circ} \mathrm{C}(8) \\
& 37^{\circ} \mathrm{C} \rightarrow 45^{\circ} \mathrm{C}(30) \rightarrow 55^{\circ} \mathrm{C}(8) \\
& 37^{\circ} \mathrm{C} \rightarrow 43^{\circ} \mathrm{C}(30, \mathrm{~T}+) \rightarrow 55^{\circ} \mathrm{C}(8) \\
& 37^{\circ} \mathrm{C} \rightarrow 45^{\circ} \mathrm{C}(30, \mathrm{~T} \dagger) \rightarrow 55^{\circ} \mathrm{C}(8)
\end{aligned}
$$

\begin{tabular}{|c|c|c|c|c|c|}
\hline \multirow[b]{2}{*}{$\begin{array}{l}\text { Band } \\
(\mathrm{kDa})\end{array}$} & + , Induction; - , lack of induction. & \multicolumn{3}{|c|}{ Condition } & \\
\hline & $\begin{array}{l}23^{\circ} \mathrm{C} \rightarrow \\
37^{\circ} \mathrm{C}\end{array}$ & $\begin{array}{c}37^{\circ} \mathrm{C} \rightarrow \\
45^{\circ} \mathrm{C}\end{array}$ & Ethanol ${ }^{\bullet}$ & $\begin{array}{l}\text { Mercury (as } \\
\text { phenylmercuric } \\
\text { acetate) }\end{array}$ & $\begin{array}{l}\text { Cadmium } \\
\left(\text { as } \mathrm{CdCl}_{2} \text { ) }\right.\end{array}$ \\
\hline 135 & - & - & - & - & + \\
\hline 98 & - & + & - & - & - \\
\hline 88 & - & - & - & + & - \\
\hline $84-85$ & + & + & - & + & - \\
\hline $80-82$ & - & + & + & + & - \\
\hline 76 & - & + & - & - & - \\
\hline $70-73$ & + & + & - & - & - \\
\hline 68 & + & - & + & - & - \\
\hline 64 & + & - & + & - & - \\
\hline $54-56$ & + & + & - & - & - \\
\hline $46-48$ & + & - & + & - & - \\
\hline $38-43$ & + & - & + & - & - \\
\hline 34 & - & + & + & - & - \\
\hline 26 & - & + & - & - & - \\
\hline 22 & + & - & - & - & - \\
\hline 18 & + & + & - & - & - \\
\hline
\end{tabular}

c.f.u. (percentage of control)

$$
\begin{aligned}
& 100 \\
& 98 \\
& 98 \\
& <0 \cdot 2^{*} \\
& 52 \\
& 64 \\
& <0 \cdot 2^{*} \\
& 6
\end{aligned}
$$

- Below the limit of detection.

† To test the requirement for protein synthesis, $3.5 \mu \mathrm{g}$ trichodermin $\mathrm{ml}^{-1}$ was added $20 \mathrm{~min}$ before the shift to $43^{\circ} \mathrm{C}$ or $45^{\circ} \mathrm{C}$.

Table 2. Induction of stress proteins by different forms of stress

* Determined visually from previously published gels (Dabrowa \& Howard, 1984; Zeuthen et al., 1988).

of HSPs at about 90, 80 and $70 \mathrm{kDa}$ (Ashburner \& Bonner, 1979; Dabrowa \& Howard, 1984; Ingolia et al., 1982; Kelly \& Schlesinger, 1982; Welch \& Feramisco, 1984). In addition, an HSP similar to the $34 \mathrm{kDa}$ protein that has been recorded among the heat-stress response proteins of Neurospora crassa (Plesofsky-Vig \& Brambl, 1985) was observed. The synthesis of HSPs in C. albicans was not accompanied by as severe a depression of normal protein synthesis as that seen in N. crassa (Plesofsky-Vig \& Brambl, 1985) or as seen in C. albicans exposed to ethanol stress (Zeuthen et al., 1988). Some cellular proteins were synthesized to the same extent at $45^{\circ} \mathrm{C}$ as they had been at $37^{\circ} \mathrm{C}$ (Fig. 1). Our efforts to completely suppress normal protein synthesis whilst allowing HSP synthesis, by exposure of cells to temperatures higher than $46^{\circ} \mathrm{C}$ did not work and at $48^{\circ} \mathrm{C}$ all protein synthesis stopped.

The proteins synthesized in response to different forms of stress may be determined by the nature of the stress (Gottesman, 1984). It is also known that some proteins associated with one 
Table 3. HSPs produced by a germination competent strain (300) and a germination deficient strain (300-SG) of C. albicans

Results from a temperature shift of from $23^{\circ} \mathrm{C}$ to $37^{\circ} \mathrm{C}$ (Dabrowa \& Howard, 1984) and from $37^{\circ} \mathrm{C}$ to $45^{\circ} \mathrm{C}$ (present study) were combined for this comparison. Only HSP bands were recorded.

$\begin{array}{ccc}\begin{array}{cc}\text { Band } \\ (\mathrm{kDa})\end{array} & \overbrace{300} & 300-\mathrm{SG} \\ 98 & + & + \\ 84-85 & + & + \\ 80-82 & + & + \\ 76 & + & + \\ 70-73 & + & + \\ 68 & + & + \\ 64 & + & + \\ 54-56 & + & - \\ 46-48 & + & + \\ 38-43 & + & + \\ 34 & + & + \\ 26 & + & + \\ 33 & + & + \\ 18 & + & +\end{array}$

stimulant can be evoked by other stresses. A summary of the proteins synthesized by C. albicans in response to five different stimulants is shown in Table 2. Nine HSPs were detected in each of the temperature shifts but only four were common to both temperature shift regimes. Thus, five distinctive HSPs were found in each of the temperature shifts designed to be environmentally stressful. Four of the six proteins formed in response to ethanol stress are also HSPs. It is therefore not unexpected that exposure to ethanol induces partial thermotolerance. Such crossprotection between different types of stress has been reported in Saccharomyces cerevisiae (Plesset et al., 1982), in N. crassa (Guy et al., 1986; Kapoor \& Lewis, 1987), and in prokaryotic cells (Jenkins et al., 1988). The degree of thermotolerance afforded by ethanol exposure was modest in comparison to that provided by preincubation at a supraoptimal temperature (Fig. 6).

The search for the function of stress proteins has not been highly productive. Much of the current data suggest a structural role rather than a catalytic activity for HSPs (Schlesinger, 1986), although the exact function of stress proteins has yet to be defined (Schlesinger, 1986). HSPs and perhaps other stress-response proteins may also be involved in cell cycle control and differentiation (Carper et al., 1987; Lindquist, 1986; Schlesinger, 1986; Wanner et al., 1985). LeJohn \& Braithwaite (1984) have indicated that while nutritional shock proteins might be involved in sporulation of Achlya klebsiana, HSPs were probably not. The fact that 12 of the 14 HSPs formed by strain 300 (Table 2; Dabrowa \& Howard, 1984; Zeuthen et al., 1988) were also formed by the germination-defective variant, strain 300-SG (Table 3), makes it unlikely that they play a role in regulation of germination. This supposition is further supported by the fact that a temperature shift does not take place before tissue invasion by $C$. albicans as it does in dimorphic zoopathogens such as Histoplasma capsulatum (Schlesinger, 1986; Lambowitz et al., 1983).

Early work on phase-specific proteins in C. albicans was initiated both to discover potential regulatory molecules and to use proteins expressed at $37^{\circ} \mathrm{C}$ as potential probes for antibody responses of patients (Ahrens et al., 1983; Brown \& Chaffin, 1981; Brummel \& Soll, 1982; Dabrowa \& Howard, 1984; Dabrowa et al., 1970; Manning \& Mitchell, 1980; Syverson et al., 1975). The proteins noted in those studies were, for the most part, produced in response to heat or nutritional shock (Dabrowa \& Howard, 1984). That result would not of itself detract from the usefulness of such stress-response proteins as markers of an immune response. Indeed, it has been reported that a major immunogenic protein in Schistosoma mansoni is homologous to HSP-70 (Hedstrom et al., 1987). We tried a pilot study of the interaction of nine HSPs reported herein with a polyclonal rabbit anti-Candida serum. A representative SDS-PAGE gel of proteins 
was Western-blotted with the serum. The results were inconclusive, however, because the serum detected both HSPs and proteins normally synthesized by the cells. Perhaps probes more carefully prepared by adsorption or constructed from monoclonal antibodies will be more revealing.

Germination of the blastoconidia of $C$. albicans takes place at $37^{\circ} \mathrm{C}$, at a neutral $\mathrm{pH}$, and in response to a variety of nutritional signals (Dabrowa \& Howard, 1983). Two of the nutritional stimulants of germ-tube formation are glucose starvation and nitrogen limitation (Dabrowa \& Howard, 1983; Lee et al., 1975). Both of these are forms of nutritional stress and may modulate the pattern of protein synthesis (Dabrowa \& Howard, 1988). The results of studies by LeJohn \& Braithwaite (1984) clearly suggest that nutrition-shock proteins are involved in regulating sporulation of the water mould Achlya klebsiana. A similar role for proteins whose synthesis is regulated by nutritional constraints in $C$. albicans has yet to be demonstrated.

This investigation was supported by Public Health Service grant AI-16252 from the National Institute of Allergy and Infectious Diseases, NIH, Bethesda, MD. We are grateful to Eufemia Tsui, Janet Chu and Peter Sokoloff for skilful technical assistance and we thank Lois Howard for preparing the manuscript. We thank Rishab Gupta and Nina Dabrowa, University of California, Los Angeles, for reading and criticizing the manuscript. We are grateful to J. E. Edwards, Jr, Harbor/UCLA, for the sample of polyclonal rabbit anti-Candida serum. This is publication no. 140 of the Collaborative California Universities-Mycology Research Unit (CCU-MRU).

\section{REFERENCES}

Ahrens, J. C., Daneo-Moore, L. \& Buckley, H. R. (1983). Differential protein synthesis in Candida albicans during blastospore formation at $24.5{ }^{\circ} \mathrm{C}$ and during germ tube formation at $37^{\circ} \mathrm{C}$. Journal of General Microbiology 129, 1133-1139.

ASHBURNER, M. \& BONNER, J. J. (1979). The induction of gene activity in Drosophila by heat shock. Cell 17, 241-254.

AtKinson, B. G. \& Dean, R. L. (1985). Effect of stress on the gene expression of amphibian, avian, and mammalian blood cells. In Changes in Eukaryotic Gene Expression in Response to Environmental Stress, pp. 159-181. Edited by B. G. Atkinson \& D. B. Walden. New York: Academic Press.

BORG, M. \& RUCHEL, R. (1988). Expression of extracellular proteinase by proteolytic Candida spp. during experimental infection of oral mucosa. Infection and Immunity 56, 626-631.

Brown, L. A. \& Chaffin, W. L. (1981). Differential expression of cytoplasmic proteins during yeast bud and germ tube formation in Candida albicans. Canadian Journal of Microbiology 27, 580-586.

Brummel, M. \& Soll, D. R. (1982). The temporal regulation of protein synthesis during synchronous bud or mycelium formation in the dimorphic yeast Candida albicans. Developmental Biology 89, 211-224.

Carper, S. W., Duffy, J. J. \& Gerner, E. W. (1987). Heat shock proteins in thermotolerance and other cellular processes. Cancer Research 47, 5249-5255.

Dabrowa, N. \& Howard, D. H. (1983). Blastoconidium germination. In Fungi Pathogenic for Humans and Animals, Part A, Biology, pp. 525-545. Edited by D. H. Howard. New York: Marcel Dekker.

Dabrowa, N. \& Howard, D. H. (1984). Heat shock and heat stroke proteins observed during germination of the blastoconidia of Candida albicans. Infection and Immunity 44, 537-539.

Dabrowa, N. \& HowaRD, D. H. (1988). Nutritionally induced changes in protein synthesis of Candida albicans. Abstracts of the Annual Meeting of the American Society for Microbiology F2, 392.

Dabrowa, N., Howard, D. H., LaNdaU, J. N. \& SCHECHTER, Y. (1970). Synthesis of nucleic acids and proteins in the dimorphic forms of Candida albicans. Sabouraudia 8, 163-169.

GibBons, G. F. \& Howard, D. H. (1986). Arginine auxotrophs of Candida albicans deficient in arginosuccinate lyase. Journal of General Microbiology 132 , 263-268.

Gopal, P., Sullivan, P. A. \& Shepherd, M. G. (1982). Enzymes of $N$-acetylglucosamine metabolism during germ-tube formation in Candida albicans. Journal of General Microbiology 128, 2319-2326.

GotTESMAN, S. (1984). Bacterial regulation: global regulatory networks. Annual Review of Genetics 18, 415-441.

Guy, C. L., Plesofsky-Vig, N. \& Brambl, R. (1986). Heat shock protects germinating conidiospores of Neurospora crassa against freezing injury. Journal of Bacteriology 167, 124-129.

Hedstrom, R., Culpepper, J., Harrison, R. A., Agabian, N. \& NewPORT, G. (1987). A major immunogen in Schistosoma mansoni infections is homologous to the heat-shock protein Hsp 70. Journal of Experimental Medicine 165, 1430-1435.

Howard, D. H., Zeuthen, M. L. \& Dabrowa, N. (1986). Phenotypic characteristics of a slow-growing, nongerminative variant of Candida albicans. Journal of General Microbiology 132, 2359-2366.

Ingolia, T. D., Slater, M. R. \& Craig, E. A. (1982). Saccharomyces cerevisiae contains a complex multigene family related to the major heat-inducible gene of Drosophila. Molecular and Cellular Biology 2, 1388-1398.

Jenkins, D. E., Schultz, J. E. \& Matin, A. (1988). Starvation-induced cross protection against heat or $\mathrm{H}_{2} \mathrm{O}_{2}$ challenge in Escherichia coli. Journal of Bacteriology 170, 3910-3914. 
KAPOOR, M. \& LEWIS, J. (1987). Alteration of the protein synthesis pattern in Neurospora crassa cells by hyperthermal and oxidative stress. Canadian Journal of Microbiology 33, 162-168.

KeLly, P. M. \& Schlesinger, M. J. (1982). Antibodies to two major heat-shock proteins cross-react with similar proteins in widely divergent species. Molecular and Cellular Biology 2, 267-274.

Lambowitz, A. M., Kobayashi, G. S., Painter, A. \& MEDOFF, G. (1983). Morphogenesis in the pathogenic fungus Histoplasma capsulatum may be related to heat shock response. Nature, London 303, 806-808.

LeE, K. L., BUCKLEY, H. R. \& CAMPBell, C. C. (1975). An amino acid liquid synthetic medium for the development of mycelial and yeast forms of Candida albicans. Sabouraudia 13, 148-153.

LeJohn, H. B. \& Brarthwarte, C. E. (1984). Heat and nutritional shock-induced proteins of the fungus Achlya are different and under independent transcriptional control. Canadian Journal of Biochemistry and Cell Biology 62, 837-846.

LI, G. C. \& LASzLo, A. (1985). Thermotolerance in mammalian cells: a possible role for heat shock proteins. In Changes in Eukaryotic Gene Expression in Response to Environmental Stress, pp. 227-254. Edited by B. G. Atkinson \& D. B. Walden. New York: Academic Press.

LINDQUIST, S. (1986). The heat-shock response. Annual Review of Biochemistry 55, 1151-1191.

ManNING, M. \& Mitcheld, T. G. (1980). Morphogenesis of Candida albicans and cytoplasmic proteins associated with differences in morphology, strain, or temperature. Journal of Bacteriology 144, 258-273.

MORRISEY, J. H. (1981). Silver stain for proteins in polyacrylamide gels: a modified procedure with enhanced uniform sensitivity. Analytical Biochemistry 117, 307-310.

OdDs, C. (1988). Candida and Candidosis, 2nd edn. London: Baillière Tindall.

Plesofsky-Vig, N. \& Brambl, R. (1985). Heat shock response in Neurospora crassa: protein synthesis and induced thermotolerance. Journal of Bacteriology 162, 1083-1091.

Plesset, J., Palm, C. \& Mclaughlin, C. S. (1982). Induction of heat shock proteins and tolerance by ethanol in Saccharomyces cerevisiae. Biochemical and Biophysical Research Communications 108, 13401345.

RAY, T. L. \& PAYNe, C. D. (1988). Scanning electron microscopy of epidermal adherence and cavitation in murine candidiasis: a role for Candida acid proteinase. Infection and Immunity 56, 1942-1949.

SCHLESINGER, M. J. (1985). Stress response in avian cells. In Changes in Eukaryotic Gene Expression in Response to Environmental Stress, pp. 183-195. Edited by B. G. Atkinson \& D. B. Walden. New York: Academic Press.

SCHLESINGER, M. J. (1986). Heat shock proteins: the search for functions. Journal of Cell Biology 103, 321325.

ShePHerd, M. G., Yin, Cy. Y., RAM, S. P. \& Sullivan, P. A. (1980). Germ tube induction in Candida albicans. Canadian Journal of Microbiology 26, 21-26.

Syverson, R. E., BuCkley, H. R. \& Campbell, C. C. (1975). Cytoplasmic antigens unique to the mycelial or yeast phase of Candida albicans. Infection and Immunity 12, 1183-1188.

W ANNER, R., Forster, H., Mendgen, K. \& Staples, R. C. (1985). Synthesis of differentiation-specific proteins in germlings of the wheat stem rust fungus after heat shock. Experimental Mycology 9, 279-283.

WelCh, W. J. \& Feramisco, J. R. (1984). Nuclear and nucleolar localization of the 72000 -dalton heat shock protein in heat-shocked mammalian cells. Journal of Biological Chemistry 259, 4501-4513.

Zeuthen, M. L., Dabrowa, N., Aniebo, C. M. \& HowARD, D. H. (1988). Ethanol tolerance and the induction of stress proteins by ethanol in Candida albicans. Journal of General Microbiology 134, 13751384. 